Прокопів М.M.

\title{
Характеристика оптимізованої системи надання медичної допомоги хворим на цереброваскулярні хвороби на рівні мегаполісу - м. Кисва
}

\author{
Національний медичний університет імені О.О. Богомольця, м. Київ, Україна
}

prokopivmm@gmail.com

\author{
Прокопив М.M. \\ Характеристика оптимизированной системы \\ оказания медицинской помощи больным \\ с цереброваскулярными заболеваниями \\ на уровне мегаполиса - г. Киева \\ Национальный медицинский университет \\ имени А.А. Богомольца, г. Киев, Украина
}

Prokopiv M.M.

Characteristics of optimized system of medical care for patients with cerebrovascular diseases at the level of megapolis - Kyiv

National Medical University named after O.O. Bohomolets, Kyiv, Ukraine

\section{Вступ}

В ході проведеного нами дослідження було встановлено високий рівень захворюваності населення м. Києва на цереброваскулярні хвороби (ЦВХ) та мозкові інсульти (MI) та смертності населення в їх наслідок $[1,2]$. Також виявлено високий рівень факторів ризику вказаних хвороб та низький рівень здорового способу життя населення $[3,4]$. Крім того виявлено недоліки організаційного та управлінського характеру в надання медичної допомоги населенню при ЦВХ та МІ $[5,6]$.

Все наведене вище стало підставою необхідності оптимізації медичної допомоги населенню м. Києва при ЦВХ та МI.

Мета - розробити та представити оптимізовану систему надання медичної допомоги хворим на цереброваскулярні хвороби на рівні мегаполісу.

\section{Матеріали та методи}

Матеріалами дослідження стали результати попередніх особистих досліджень та рекомендації ВООЗ 3 питання, що вивчається. В ході дослідження використано бібліосемантичний метод та метод структурно-логічного аналізу.

\section{Результати дослідження та їх обговорення}

Базуючись на отриманих в ході попереднього дослідження результатах була розроблена кластерна модель складових медичної допомоги при цереброваскулярних хворобах.

Методологія створення кластерів базувалася на тому, що сутність кожного 3 них спрямований на досягнення кінцевої мети: підвищення доступності та ефективності медичної допомоги населенню мегаполісу при ЦВХ та МI і зниження тягара внаслідок захворюваності населення на них.
Нами виділено чотири основних кластери складових медичної допомоги при цереброваскулярних хворобах. Цими кластерами є: профілактика розвитку ЦВХ, профілактика розвитку МI, надання медичної допомоги (амбулаторної, екстреної та стаціонарної) при ЦВХ та МІ та забезпечення супроводом осіб, що перенесли МI.

При міжсекторальному підході до вирішення проблеми забезпечення населення доступною та ефективною допомогою при ЦВХ та МI за кожним кластером визначенні виконавці. В цілому, в залежності від визначених складових, виконавцями $є$ медичні працівники служби ПМСД, ЕМД та спеціалізованої медичної допомоги, приватні 3О3, система громадського здоров'я, система паліативної допомоги, соціальні служби, громадські організації.

Базуючись на кластерній моделі складових медичної допомоги при цереброваскулярних хворобах нами розроблена оптимізована система надання медичної допомоги хворим на цереброваскулярні хвороби. Вона представлена на рисунку.

Розробка оптимізованої функціональноорганізаційної системи надання медичної допомоги в мегаполісі хворим на цереброваскулярні хвороби на сучасному етапі розвитку суспільства та реформування галузі охорони здоров'я базувалась на тому, що ефективна діяльність системи залежить від:

- рівня ресурсного забезпечення системи, який має відповідати існуючому науково-доказовому його обгрунтуванню та чинній законодавчій базі;

- рівня управління даними ресурсами та забезпеченню його використання;

- організації діяльності системи та ступеню взаємодії усіх учасників системи;

- готовності населення відповідально ставитися до особистого здоров'я та здоров'я членів своєї родини і при необхідності вміло використовувати існуючу систему до збереження здоров'я та отамання медичної допомоги. 


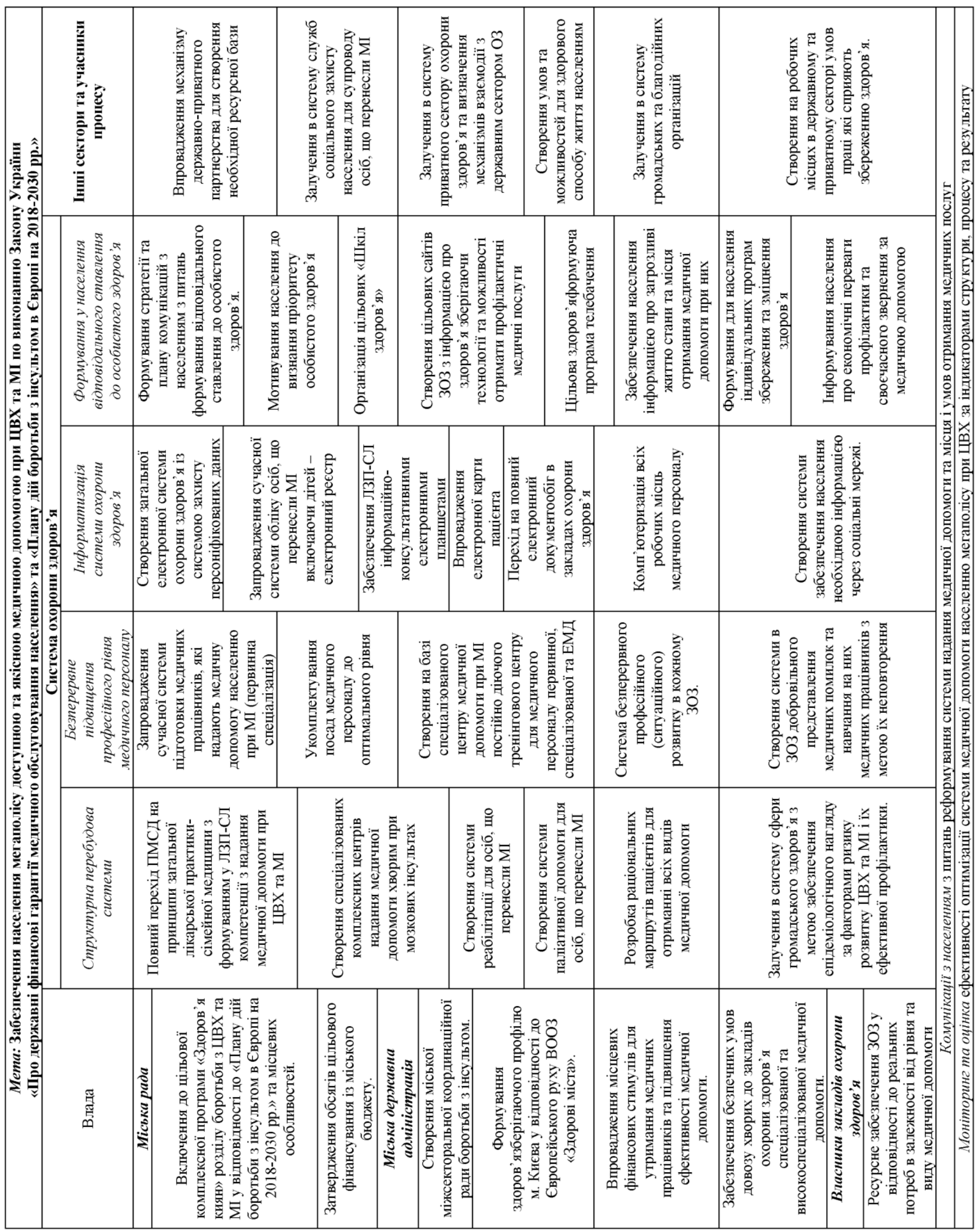

Рис. Оптимізована функціонально-організаційна система надання медичної допомоги в мегаполісі хворим на цереброваскулярні хвороби на сучасному етапі розвитку суспільства та реформування галузі охорони здоров’я 
Центральним елементом системи є населення м. Києва, яке розділяється на наступні групи цільового впливу: здорові, населення, що має фактори ризику розвитку ЦВХ, хворі на ЦВХ, хворі на МІ, особи, що перенесли MI. Таким чином система $\epsilon$ пацієнтоорієнтованою.

Стратегічним напрямом системи є зниження тягаря хвороб в тому числі захворюваності та смертності населення міста внаслідок ЦВХ.

Тактичним напрямком системи нами визначено забезпечення населення доступною, якісною та ефективною медичною допомогою при ЦВХ та МI та підвищення ефективності профілактичної роботи і формування у населення відповідального ставлення до особистого здоров'я та здоров'я членів своєї родини.

Обгрунтована, розроблена та запропонована оптимізована функціонально-організаційна система надання медичної допомоги в мегаполісі хворим на цереброваскулярні хвороби на сучасному етапі розвитку суспільства та реформування галузі охорони здоров'я базується на існуючий системі медичного забезпечення населення міста, яка удосконалена за рахунок оптимізації системи управління нею, забезпечення міжсекторального підходу та функціонально-організаційної оптимізації. До системи включені:

- Існуючі елементи діяльність яких удосконалена. це заклади охорони здоров'я первинної, спеціалізованої та екстреної медичної допомоги, приватні 303, що надають медичну допомогу при ЦВХ та МІ, які укладають договори на фінансування 3 Національною агенцією охорони здоров'я України з надання відповідної медичної допомоги.

\section{- Нові елементи моделі є наступні.}

1) Включення до системи законодавчої та виконавчої влади міста 3 визначенням для них цільових задач та функцій в тому числі включення до цільової комплексної програми «Здоров'я киян» розділу боротьби 3 ЦВХ та МІ у відповідності до «Плану дій боротьби 3 інсультом в Свропі на 2018-2030 рр.» та місцевих особливостей 3 визначенням обсягів та джерел іiї фінансування;

2) Включення в систему інших секторів та учасників процесу в тому числі впровадження механізму державно-приватного партнерства для створення необхідної ресурсної бази, залучення в систему служб соціального захисту населення для супроводу осіб, що перенесли MI, залучення в систему громадських та благодійних організацій;

3) В напрямку структурної перебудови системи організації медичної допомоги населенню міста новим $\epsilon$ створення комплексних спеціалізованих центрів надання медичної допомоги хворим при мозкових інсультах із розробкою їх організаційної структури та маршруту пацієнта, створення системи реабілітаційної та паліативної допомоги;

4) 3 метою забезпечення епідеміологічного нагляду за ризиками розвитку ЦВХ та МІ і підвищення ефективності профілактичної діяльності залучення до комплексних заходів боротьби з МІ системи громадського здоров'я;

5) В напрямку безперервного підвищення професійного рівня медичного персоналу, який надає медичну допомогу населенню при ЦВХ та МІ принципово новими напрямками діяльності $\epsilon$ запровадження їх спеціальної підготовки до даного виду діяльності;

6) В розділі моделі «Інформатизація системи охорони здоров'я» представлено комплекс заходів, які мають забезпечити використання комунікацій та соціальної мобілізації в напрямку мотивації населення до відповідального ставлення до особистого здоров'я та навчання його здоровому (оптимальному) способу життя, забезпечити ведення в місті єдиного реєстру пацієнтів, що перенесли MI, і забезпечити перехід на повний електронний документообіг, а також збір і обробку статистичних даних в 303 в яких надається вказана медична допомога;

7) Що стосується населення міста на відміну від традиційного формування у населення здорового способу життя нами акцентується увага на формуванні у населення відповідального ставлення до особистого здоров'я та здоров'я членів родини. Цей напрямок діяльності передбачає формування у населення економічно обгрунтованої мотивації до профілактики та своєчасного звернення за медичною допомогою при загрозливих життю станах та інформування населення щодо місця звертання за необхідною медичною допомогою при таких станах.

Важливою складовою забезпечення впровадження системи є моніторинг та оцінка ефективності впровадження запропонованих інновацій та їх вплив на результати медичної допомоги населенню при ЦВХ та МІ. Для цього розробляються індикатори структури, процесу, результату. Вказані індикатори розробляються щорічно з урахуванням базових даних, цілей та показників, які необхідно досягти в результаті виконання цільової міської програми.

Перспективи подальших досліджень пов'язані 3 вивченням ефективності впровадження запропонованих інновацій в систему охорони здоров'я м. Києва.

\section{Висновки}

Застосування обгрунтованої та представленої оптимізованої системи надання медичної допомоги хворим на цереброваскулярні хвороби та мозкові інсульти на рівні мегаполісу дозволить рівень захворюваності та смертності населення міста внаслідок вказаної патології.

\section{Література}

15. Слабкий Г.О. Епідеміологія цереброваскулярних хвороб серед жителів міста Києва / Г.О. Слабкий, М.М. Прокопів // Вісник соціальної гігієни та організації охорони здоров’я України. - 2019. - № 4 (82). - С. 10-15. 
16. Прокопів М.М. Якість життя мешканців мегаполісу, що перенесли церебральний інсульт / М.М. Прокопів // Україна. Здоров’я нації. - 2020. - № 1 (58). - С. 43-46.

17. Прокопів М.М. Фактори ризику розвитку цереброваскулярних хвороб у жителів мегаполіса / М.М. Прокопів, Г.О. Слабкий // Український вісник медико-соціальної експертизи. - 2019. - № 3-4 (33-34). - С.7-12.

18. Фактори ризику, структура та наслідки гострого періоду інсульту у місті Києві за результатами прагматичного спостереження / Рогоза С.В., Трепет Л.М., Вакуленко Л.О. та ін. // Український медичний часопис. 2017. - № 2 (118). - C. 124-127.

19. Прокопів М.М. Стан надання медичної допомоги хворим із мозковим інсультом у м. Києві та шляхи його поліпшення / М.М. Прокопів, С.В. Рогоза // Український неврологічний журнал. - 2018. - № 1. - С. 7-12.

20. Прокопів М.М. Спроможність реформованої системи охорони здоров'я м. Києва до надання медичної допомоги хворим на церебральний інсульт / М.М. Прокопів, Г.О. Слабкий, А.Т. Яцина // Вісник соціальної гігієни та організації охорони здоров’я України. - 2020. - № 2 (84). - С. 35-38.

\section{References}

1. Slabkiy G.O. Epidemiolohiia tserebrovaskuliarnykh khvorob sered zhyteliv mista Kyieva [Epidemiology of cerebrovascular diseases among Kyiv residents]. Bulletin of social hygiene and health care organization of Ukraine. 2019; 4(82):10-15.

2. Prokopiv M.M. Yakist zhyttia meshkantsiv mehapolisu, shcho perenesly tserebralnyi insult [Quality of life of the inhabitants of the metropolis who suffered a cerebral stroke]. Ukraine. Nation's Health. 2020; 1(58): 43-46.

3. Prokopiv M.M., Slabkiy G.O. Faktory ryzyku rozvytku tserebrovaskuliarnykh khvorob u zhyteliv mehapolisa [Risk factors for the development of cerebrovascular diseases in the inhabitants of the metropolis]. Ukrainian Bulletin of Medical and Social Expertise. 2019; 3-4 (33-34): 7-12.

4. Rohoza S.V., Trepet L.M., Vakulenko L.O. ta in. Faktory ryzyku, struktura ta naslidky hostroho periodu insultu u misti Kyievi za rezultatamy prahmatychnoho sposterezhennia [Risk factors, structure and consequences of the acute period of stroke in the city of Kiev according to the results of pragmatic observation]. Ukrainian medical journal. - 2017; 2(118): 124-127.

5. Prokopiv M.M., Rohoza S.V. Stan nadannia medychnoi dopomohy khvorym iz mozkovym insultom u m. Kyievi ta shliakhy yoho polipshennia [The state of medical care for patients with stroke in Kyiv and ways to improve it]. Ukrainian Journal of Neurology. 2018; 1: 7-12.

6. Prokopiv M.M., Slabkiy G.O., Yatsyna A.T. Spromozhnist reformovanoi systemy okhorony zdorovia m. Kyieva do nadannia medychnoi dopomohy khvorym na tserebralnyi insult [The ability of the reformed health care system in Kyiv to provide medical care to patients with cerebral stroke]. Bulletin of social hygiene and health care organization of Ukraine. 2020; 2(84):35-38

Дата надходження рукопису до редакції: 27.05 .2020 p.

\footnotetext{
Мета - розробити та представити оптимізовану систему надання медичної допомоги хворим на цереброваскулярні хвороби на рівні мегаполісу.

Матеріали та методи. Матеріалами дослідження стали результати попередніх особистих досліджень та рекомендації ВООЗ з питання, що вивчається. В ході дослідження використано бібліосемантичний метод та метод структурно-логічного аналізу.

Результати. Центральним елементом обгрунтованої оптимізованої системи є населення м. Києва яке розділяється на наступні групи цільового впливу: здорові, населення, що має фактори ризику розвитку цереброваскулярних хвороб, хворі на цереброваскулярні хвороби, хворі на мозкові інсульти, особи, що перенесли мозкові інсульти. Таким чином система є пацієнтоорієнтованою.

Стратегічним напрямом системи є зниження тягаря хвороб в тому числі захворюваності та смертності населення міста внаслідок цереброваскулярних хвороб.

Тактичним напрямком системи визначено забезпечення населення доступною, якісною та ефективною медичною допомогою при цереброваскулярних хворобах та мозкових інсультах та підвищення ефективності профілактичної роботи і формування у населення відповідального ставлення до особистого здоров'я та здоров'я членів своєї родини.

Висновки. Застосування обгрунтованої та представленої оптимізованої системи надання медичної допомоги хворим на цереброваскулярні хвороби та мозкові інсульти на рівні мегаполісу дозволить рівень захворюваності та смертності населення міста внаслідок вказаної патології.
}

Ключові слова: мегаполіс, цереброваскулярні хвороби, медична допомога, оптимізована система.

Цель - разработать и представить оптимизированную систему оказания медицинской помощи больным с цереброваскулярными заболеваниями на уровне мегаполиса. 
Материалы и методы. Материалами исследования стали результаты предыдущих личных исследований и рекомендации ВОЗ по изучаемому вопросу. В ходе исследования использованы библиосемантический метод и метод структурно-логического анализа.

Результаты. Центральным элементом обоснованной оптимизированной системы является население г. Киева, которое разделяется на следующие группы целевого влияния: здоровые, население, имеющее факторы риска развития цереброваскулярных заболеваний, больные с цереброваскулярными заболеваниями, больные с мозговыми инсультами, лица, перенесшие мозговые инсульты. Таким образом, система является пациент ориентированной.

Стратегическим направлением системы является снижение тяжести заболеваний, в том числе заболеваемости и смертности населения города вследствие цереброваскулярных болезней.

Тактическим направлением системы определено обеспечение населения доступной, качественной и эффективной медицинской помощью при цереброваскулярных заболеваниях и мозговых инсультах, а также повышение эффективности профилактической работы и формирование у населения ответственного отношения к собственному здоровью и здоровью членов своей семьи.

Выводы. Использование обоснованной и представленной оптимизированной системы оказания медицинской помощи больным с цереброваскулярными заболеваниями и мозговыми инсультами на уровне мегаполиса позволит снизить уровень заболеваемости и смертности населения города вследствие указанной патологии.

Ключевые слова: мегаполис, цереброваскулярные заболевания, медицинская помощь, оптимизированная система.

Goal of research: to develop and present an optimized system for providing medical care to patients with cerebrovascular disease at the megapolis level.

Materials and methods. The results of previous personal studies and the WHO recommendations on the issue being studied were used as the materials of research. Bibliosemantic method and the method of structural-and-logical analysis were applied in the course of study.

Results. The central element of a justified optimized system is the population of Kyiv, which is divided into the following groups of targeted influence: healthy persons, population with risk factors for the development of cerebrovascular diseases, patients with cerebrovascular diseases, patients with brain strokes, persons who suffered brain strokes. Thus, the system is patient-oriented.

The strategic direction of the system is the reduction of the burden of diseases, including morbidity and mortality of the population of a city due to cerebrovascular disease.

The tactical direction of the system is determined by providing the population with affordable, high-quality and effective medical care for cerebrovascular disease and cerebral strokes and improving the effectiveness of preventive work and forming a responsible attitude to the personal health and health of the family members in the population.

Conclusions. The use of a justified and presented optimized system of medical care for patients with cerebrovascular disease and cerebral strokes at the megapolis level will give possibility to reduce the incidence and mortality of the city population due to this pathology.

Key words: megapolis, cerebrovascular diseases, medical care, optimized system.

\section{Відомості про автора}

Прокопів Марія Мирославівна - к.мед.н., доцент, доцент кафедри неврології Національного медичного університету імені О.О. Богомольця; м. Київ, бул. Т. Шевченка, 13.

prokopivmm@gmail.com. 